\title{
Can children's spelling of schwa vowels in stems be improved?
}

\section{Pode-se melhorar a escrita das vogais indistintas pelas crianças?}

\author{
João Rosa ${ }^{1}$ \\ Terezinha Nunes ${ }^{2}$
}

\begin{abstract}
Children in the early grades of primary school do not seem to have much awareness of morphemes. In this study, a priming paradigm was used to try to detect early signs of morphological representation of stems through a spelling task presented to Portuguese children $(\mathrm{N}=396$; age range 6 to 9 years). Primes shared the stem with the targets and contained well-articulated, stressed vowels; the stems of the target words contained non-stressed schwa vowels, which typically result in spelling difficulties. If priming proved effective, the well-articulated vowels in the prime should lead to improvement in the spelling of the schwa vowels in the targets. Primes were presented in two conditions: in only-oral or in oral-plus-written form. Effectiveness of priming was assessed by comparison with a no-priming condition. There was a significant interaction between priming effects and grade. No priming effects were detected in 6- and 7-year-old children; oral-plus-written priming produced higher rates of correct vowel spelling for 8- and 9-year-olds; only-oral priming was effective in improving the vowel spelling of 9-year-olds. Thus the older children used morphological information under priming conditions but there is no evidence to suggest that younger children did so.
\end{abstract}

Keywords: Morphological priming; spelling of stems; morphology; spelling.

\section{RESUMO}

Nos primeiros anos da escola primária, as crianças parecem não ter muita consciência dos morfemas. Neste estudo, o paradigma de sensibilização (priming) foi usado para tentar detectar sinais precoces da representação

$1 \mathrm{PhD}$ em Psicologia pela Oxford Brookes University. Professor Coordenador na Escola Superior de Educação de Lisboa - Portugal, jmsrosa@hotmail.com

$2 \mathrm{PhD}$ em Psicologia pela City University of New York. Professora Titular de Psicologia da Educação, University of Oxford - Inglaterra, terezinha.nunes@education.ox.ac.uk 
morfológica de radicais numa tarefa de escrita apresentada a crianças portuguesas ( $\mathrm{N}=396$; com idades entre 6 e 9 anos). Os estímulos antecedentes (primes) compartilhavam o radical com os alvos e continham vogais tônicas bem articuladas; os radicais das palavras alvo continham vogais scwha (indistintas) átonas, que tipicamente resultam em dificuldades ortográficas. Se o antecedente se mostrar efetivo, a presença de vogais bem articuladas nos estímulos antecedentes deverá resultar na melhoria da ortografia das vogais schwa nas palavras alvo. Os antecedentes foram apresentados em duas condições: forma oral apenas e forma oral mais escrita. A eficácia da sensibilização (priming) foi avaliada pela comparação com uma condição em que as crianças não eram expostas aos antecedentes (no-priming). Observou-se uma interação significativa entre os efeitos de sensibilização e a série escolar. Não foram detectados efeitos de sensibilização em crianças de 6 e 7 anos; a sensibilização oral e escrita produziu os maiores índices de uso da vogal correta em crianças de 8 e 9 anos; a sensibilização apenas oral foi efetiva na melhoria do uso das vogais apenas em crianças de 9 anos. Portanto, as crianças mais velhas utilizaram a informação morfológica sob condições de sensibilização, mas não há evidência para sugerir que as crianças mais novas o tenham feito.

Palavras-chave: priming morfológico; escrita de radicais; morfologia; ortografia.

\section{Introduction}

This study aims to investigate whether it is possible to improve children's spelling of schwa vowels through the use of morphological primes - thus activating their implicit knowledge of morphology. The study was carried out in European Portuguese, whose orthography is generally transparent. However, when a suffix is added to a base form, there is often a shift in stress and a clearly pronounced vowel in the base form becomes a schwa vowel in the derived form. For example, "tambor" (drum) has a well articulated vowel, represented by the letter "o", but "tamborilar" (to drum) has a schwa vowel in the same position, closer to the semivowel/w/. Portuguese primary school children often misspell the vowels in the derived form in these cases because these vowels are not predictable from pronunciation. This study investigated whether it is possible to improve children's spelling of derived words containing a schwa vowel through priming techniques. If priming proves effective in improving the spelling of a vowel that cannot be identified from phonology, it will be concluded that children can use implicit knowledge to represent morphology in spelling. 
So far as we know, this is the first time that this method is used in the study of children's spelling processes.

Relevant examples, even though posing a different type of problem, can also be found in Brazilian Portuguese. In the variety of language spoken in Brazil, the final sound of words ending in "l", such as "mel", is not distinct from the non-stressed final sound in "pau": both words end in the same semivowel /w/ (FARACO, 1992). Young children often find it difficult to spell words correctly ending in "l", but a morphological strategy could be used to help them. If they can find a derived word, in which a suffix is added, they might be able to know whether the base form is spelled with "l" or "u". For example, "melado", derived from "mel", contains the stem with the "l" clearly pronounced, so the base form must be spelled with "l". In contrast, "paulada", derived from "pau", contains the semivowel $/ \mathrm{w} /$, so the base form must be spelled with the semivowel. Other examples of words that end in the semivowel /w/ whose spelling could be predicted form their derived forms as having an "l" at the end are "mal", predicted from "malícia", "sal", predicted from "saleiro", e "sol", predicted from "ensolarado".

It is generally accepted that priming works at the level of implicit knowledge because priming paradigms involve on-line tasks (i.e., tasks in which participants speak, read or write), and the representation of linguistic sub-lexical units in on-line tasks is processed too quickly for people to be aware of the nature of the representations they are using (Karmiloff-Smith, 1992). Evidence from word recognition (KEMPLEY; MORTON, 1982) and lexical decision experiments (EMMOREY, 1989; FORSTER; AZUMA, 2000; LAUDANNA; BADECKER; CARAMAZZA, 1989; LAUDANNA; BADECKER; CARAMAZZA, 1992; LAUDANNA; CERMELE; CARAMAZZA, 1997; RAVEH; RUECKL, 2000) with adults suggests that the ability to recognise a target word is facilitated by a prime that shares its stem. A prime (e.g., harm) that contains the same stem as a target (harmless) speeds the recognition of the target word, whereas it inhibits the recognition of a phonologically related but morphologically unrelated target (harmony). This evidence suggests that words are represented in the mental lexicon not only as whole words but also analysed in morphemes. These studies further demonstrated that priming effects can also be observed with pseudowords in lexical decision tasks (CARAMAZZA; LAUDANNA; ROMANI, 1988). This suggests that the representation of morphemes must not be viewed simply as entries in the mental lexicon: adults must be parsing pseudowords according to a morphemic structure at some stage when they are making lexical decisions about these items (CHIALANT; CARAMAZZA, 1995). It thus becomes an important question to examine when the process of analysing words into morphemes and 
obtaining analysed representations becomes available to children for executing literacy-related tasks.

There is growing evidence from developmental studies that children's awareness of morphology, assessed by off-line tasks (i.e., thinking about speaking, reading or writing), develops with age and instruction, and is related to the use of morphological representation in spelling. Nunes and Bryant (NUNES; BRYANT; BINDMAN, 1997a; 1997b; NUNES; BRYANT; OLSSON, 2003) were the first to provide clear evidence for a causal connection between awareness of morphology and spelling, through a combination of longitudinal and intervention studies. Nunes, Bryant and Bindman (1997a; 1997b) showed in a longitudinal study that the use of morphological markers in spelling is predicted by performance in morphological awareness tasks administered more than one year earlier and after controlling for the effects of age and IQ. Nunes, Bryant and Olsson (2003) further showed that training in morphological awareness improves children's spelling of words that represent morphology and flout letter-sound rules (such as "magician"). A strategy useful for spelling the last consonant in the stem of "magician" would be to identify its stem, "magic". But there is no direct evidence from on-line spelling tasks to show that increasing the likelihood of access to the stem "magic" results in more frequent use of the "c" in the spelling of "magician". Since this pioneering work, Nunes and Bryant $(2006 ; 2009)$ have provided considerable more evidence for the significance of morphological awareness for the development of children's spelling.

In the remaining of this introduction the development of the understanding of the connection between words with the same stem is analysed. The question examined here is whether this is an early development and how this acquisition relates to other measures of morphological awareness. The aim of the review is to assess whether it is likely that primary school children represent words analysed into morphemes in their mental lexicon so that they can use this representation to improve the spelling of schwa vowels under priming conditions.

Evidence regarding developmental trends in understanding the connection between words that share the same stem was first provided by Carlisle (1988). Children in grades 4, 6 and 8 were asked to supply the derived word in sentences where the base word was provided or, alternatively, to supply the base word when a derived word was provided. These tasks were performed either orally or in writing. In both the oral and in the spelling tasks, success increased from $4^{\text {th }}$ to $8^{\text {th }}$ grade. For all grade levels, success in tasks that involved fewer changes in the stem was greater than in tasks that involved more changes; phonological changes affected performance more than changes in spelling only. Performance on tasks that required the children to supply the base form was superior to performance on tasks where the children supplied the derived form. At all grade 
levels, children were better at generating forms orally than at spelling them. Carlisle concluded that the understanding of stem morphology shows significant development from the 4 th to the 8th grade. She hypothesised that direct, explicit instruction on morphological relations might be necessary to enhance children's understanding of language structure and spelling processes.

Leong (2000) examined how effective Canadian children in grades 4, 5 , and 6 (9- to 12-year-olds) were at naming the base form when the derived word was provided first, and conversely, naming the derived form when the base was presented first. The stimuli contained the same morphological transformations as in Carlisle (1988). He found that significant progress occurred from grades 4 to 6 and that naming base forms was easier than naming derived forms. He also suggested that there might be a need for systematic and explicit instruction on word morphology in schools.

Nunes, Bryant and Bindman (2006) examined the difficulty of preserving the spelling of stems across pairs of stimuli and analysed the connection between consistency in stem spelling and morphological awareness. They worked with English children from grades 2 to 4 (ages 7 to 10). The children spelled pairs of stimuli that contained the same stems. The stimuli were pairs of words (e.g., know-knowledge) or a pair formed with a word and a pseudoword (e.g., knotknotosaurus). The children's spelling was scored for consistency in the spelling of the stems, not for accuracy. For the younger group the mean score for word pairs (out of 10) was 4.1; for the older group, 5.8. Thus even the children in grade 4 (age range 9 to 10 years) were not close to ceiling in preserving the spelling of the stem across word pairs. These results indicated that consistency in the spelling of stems is not an all-or-nothing acquisition: there is some evidence of consistency in younger children and also a significant improvement with age.

The children's awareness of morphology was assessed through sentence analogy and word analogy tasks (see NUNES; BRYANT; BINDMAN, 1997a). The consistency in spelling stems was related to the children's performance in the morphological awareness tasks even after partialling out the effects of age and IQ.

Aidinis (1998) (BRYANT; NUNES; AIDINIS, 1999) replicated this progressive acquisition of consistency in spelling stems in a cross-sectional study with Greek children aged 7 to 10 years (grades 2 to 4). He also analysed the connection between awareness of morphology and consistency in spelling stems, using the same technique of words and pseudowords containing a real stem. The stems contained sounds for which at least two acceptable phonological representations exist; the correct representation is dependent on morphology. There were no changes in the stem phonology across related stimuli. The children in the age range 7-8 years scored significantly lower 
in the assessment of consistency in the spelling of stems than the 9- and 10 -year-olds. Consistency in spelling stems was significantly correlated to morphological awareness (measured through sentence analogy, word analogy and productive morphology tasks) even after partialling out the effects of age and verbal ability. Thus the improvement in consistency in spelling stems and its connection to morphological awareness was replicated in another language, Greek, which is more transparent in terms of grapheme-phoneme correspondences than English, but where morphology nevertheless plays a role in spelling.

So far no direct evidence regarding a possible facilitatory effect of priming on stem spelling has been investigated, but these results suggest that children in the middle years of primary school are likely to have not only whole word representation in their mental lexicon but also a representation analysed into stems and affixes. However, it is possible that this analytical representation is not available to children in the beginning of primary school.

Two hypotheses follow from this conclusion. First, it should be possible to document priming effects on children's spelling of schwa vowels when the base form is well-articulated, in spite of the changes in stem pronunciation from the base to the derived form. Second, this facilitatory effect of priming on stem spelling is likely to increase with age. Although performance on on-line tasks does not depend on explicit awareness during execution, the priming effect should take place if the children do represent words in their mental lexicon analysed in constituent morphemes (though they may represent words analysed phonologically) or if they are able to isolate the stem from the rest of the word, by stripping off affixes prior to spelling (see TAFT; ZHU, 1995, for a discussion of this process).

It is not possible to anticipate whether auditory or written primes will be equally effective. Auditory primes provide enough phonological cues for spelling the well-articulated vowel in the stem of the base form. Therefore, they may prove sufficient, for children who represent the word stem in their mental lexicon, to spell the derived form correctly. However, auditory priming has been considered more fragile (see EMMOREY, 1989) and thus less effective.

In order to test the hypotheses, a study was designed with three conditions: a baseline or no-priming condition, an only-oral priming condition, and an oralplus-written priming condition. Primes were base forms with a well-articulated vowel, which could be represented adequately from phonology. The measure of the effect of priming was the accuracy of spelling the schwa vowel in the target stimuli, which were derived words. If children are able to spell correctly more often the schwa vowel of a stem under priming conditions, they must have used a word analysis strategy that allows them to strip the suffix from the stem 
and to realise that the two stems - that of the prime with the well articulated vowel and that of the derived form - are the same. Evidence for this strategy would support the idea that children can analyse derived forms into stem and affixes in on-line tasks.

The language of the study was European Portuguese. The researcher was the first author, a native speaker of European Portuguese.

\section{Method}

\section{Participants}

Children $(\mathrm{N}=396)$ from grades 1 to 4 (age range from 6.6 to 9.3 years) attending three state supported primary schools in Lisbon participated in the study. All the children were born in Portugal, had European Portuguese as their first language and none had been identified for sensory, cognitive or language impairments. Table 1 displays the children's mean age (and standard deviations) by grade.

TABLE 1 - MEAN AGE, STANDARD DEVIATION AND NUMBER OF CHILDREN IN EACH GRADE LEVEL

\begin{tabular}{c|c|c|c}
\hline Grade Level & Mean & SD & N \\
\hline First & 6.97 & 0.24 & 53 \\
\hline Second & 7.43 & 0.31 & 110 \\
\hline Third & 8.50 & 0.49 & 102 \\
\hline Fourth & 9.54 & 0.55 & 131 \\
\hline
\end{tabular}

The intake of the schools reflects a high variability in children's background as described by parents' education and employment.

\section{Design}

Pairs of base (primes) and derived (target) words (24) were elaborated; primes always contained a stressed well-articulated vowel in the stem whereas 
the targets contained non-stressed, schwa vowels in the corresponding position. Base and derived word pairs were chosen from low-frequency words, with a frequency of four or less in a corpus developed by the first researcher. This corpus is based on frequency counts of printed words in school reading books used in the teaching of reading and spelling in Portuguese primary schools, from 1 st to 4 th grade. Low-frequency words were chosen because previous studies have shown that high-frequency primes are less effective (BOWERS, 2000; GIRAUDO; GRAIGNER, 2000).

In order to increase variability in scores and the possibility of generalising across stimuli, three types of stimulus-pairs were included in the task.

In the first type of stimulus pair, in which the base form contained a wellarticulated vowel, open or closed, represented in writing by the letter "o". The spelling is the same in the derived form but in fluent speech the vowel is replaced with a poorly articulated schwa vowel or the semivowel /w/. An example of a base form with an open vowel in the stem and a schwa vowel in the derived form is the pair of words "negócio - negociante" (business - businessperson); in the pair "tambor - tamborilar" (drum - to drum) the stem in the base form contains a closed vowel.

In the second type of stimulus pair, the base form contains a well-articulated vowel, open or closed, represented in writing by the letter " $\mathrm{e}$ ", which is replaced in the pronunciation of the derived form by the semivowel $/ \mathrm{j} /$ - as in the pair "ceia - cear" (dinner - to dine). It must be noted that in the Lisboan dialect the vowel in the base form can sound as a closed [a], (similar to the English vowel in "but"). A preliminary analysis will be carried out to investigate the possibility of confounding the results by the use of the letter "a" in the spelling of these stimuli.

In the third type of stimulus pair, the well-articulated vowel in the stem is represented by the letter " $\mathrm{e}$ "; in fluent speech, the vowel is omitted in the derived form - as in the pair "martelo - martelar" (hammer - to hammer), resulting in a consonant cluster, pronounced as $/ \mathrm{tl} /$.

In all the pairs, in spite of the phonological changes, the stem vowel is preserved in the spelling of the derived word.

Three Levels of Morphological Priming (no-priming; only-oral priming; oral-plus-written priming) were used. Each child spelled 24 stimuli, which were not a complex assignment even for the younger children. Intact classes at each grade level were randomly assigned to a cell with the restriction that each cell received a class before any cell could receive a second one. Table 2 gives an overview of the design and an example of the materials for each condition. 


\begin{tabular}{l|l|l}
\hline \multicolumn{3}{c}{ Level of Morphological Priming } \\
\hline \multicolumn{1}{c|}{ No-priming } & \multicolumn{1}{c}{ Only-oral priming } & Oral-plus-written priming \\
\hline \begin{tabular}{l} 
Condition 1 $(\mathrm{n}=132)$ \\
\hline 24 target words presented
\end{tabular} & $\begin{array}{l}\text { Condition 2 }(\mathrm{n}=133) \\
\text { 24 target words presented } \\
\text { in oral sentences that do } \\
\text { not contain a prime, e.g.: } \\
\text { "Ele está a tocar / } \\
\text { tain the prime, e.g.: "Ele } \\
\text { pandé a tocar /tambor/; ele } \\
\text { tamborilar/; }\end{array}$ & $\begin{array}{l}\text { Condition } 3(\mathrm{n}=131) \\
\text { está a /tamborilar/" } \\
\text { oral and written sentences } \\
\text { that contain the prime, e.g.: } \\
\text { "Ele está a tocar /tambor/; } \\
\text { ele está a /tamborilar/" }\end{array}$ \\
\hline
\end{tabular}

\section{Procedure}

The spelling task was administered in the classroom by the first author, a native speaker of European Portuguese. The children worked individually; the researchers tried to avoid copying. The target words were presented in the context of sentences. The order of stimuli was randomised to prepare the final list; the same order was used across conditions.

Children in the no-priming or baseline condition and in the only-oral priming condition were provided with an answer sheet consisting of a table with numbered rows. Children in the oral-plus-written priming condition received an answer sheet with numbered rows; each number was followed by the sentence used during task presentation. In each sentence, a blank space indicated where the target word was to be written by the children.

In the no-priming condition the sentence contained an irrelevant word replacing the item that was used as prime for the priming conditions. For example, the sentence "Ele está a tocar tambor; ele está a tamborilar", has the prime "tambor" in the first sentence and the target "tamborilar" in the second sentence. In the no-priming condition, the children heard the sentences "Ele está a tocar pandeireta; ele está a tamborilar", in which the prime "tambor" was replaced with "pandeireta" and the target remains the same, "tamborilar". Primes were not emphasised in any way. The sentences were presented in a typically fluent and colloquial speech register. The use of sentences in all conditions allowed the use of the same instructions in all conditions. 


\section{Results}

The children were given one point for using the vowels "o" and "e" in the appropriate derived words. When this scoring is applied to the non-primed condition, it provides baseline information on correct use of the vowel in the derived form.

The Cronbach's alpha for item analysis showed that the task was highly consistent (Cronbach's Alpha $=.82$ ). The scores were not significantly skewed $($ Skewness $=0.147$; Standard Error of Skewness $=0.086 ; z=1.70, p<0.05)$. Thus the assumption of normality was accepted and parametric statistics will be used in the test of the hypotheses.

Our hypotheses led to two predictions.

(1) Older children's spelling of the schwa vowels in words will improve significantly with priming; this effect may not be observed in the younger children, whose mental lexicon may not contain a separate representation for the stems and affixes. Thus a significant interaction between priming condition and grade level is predicted; consequently, the main effect of priming may or may not be significant.

(2) Only-oral priming is not expected to be as effective as oral-plus-written priming due to the fragility of oral primes. Thus only-oral priming might show beneficial effects later than oral-plus-written priming.

These predictions were tested through an analysis of variance with the spelling of the schwa vowel in the derived words as dependent variable, and priming condition and age as independent variables. Table 3 displays the summary data for these analyses, with the correct proportion and standard deviations to correct vowel spelling by Level of Morphological Priming and Grade.

TABLE 3 - MEANS AND STANDARD DEVIATIONS (IN BRACKETS) FOR THE PROPORTION OF CORRECT SPELLING OF VOWELS, BY LEVEL OF MORPHOLOGICAL PRIMING AND GRADE

\begin{tabular}{c|c|c|c}
\hline Grade & No-priming & Only-oral priming & Oral-plus-written priming \\
\hline 1 & $.43(.13)$ & $.46(.12)$ & $.46(.17)$ \\
2 & $.51(.12)$ & $.50(.12)$ & $.48(.16)$ \\
3 & $.53(.20)$ & $.62(.16)$ & $.66(.15)$ \\
4 & $.61(.16)$ & $.68(.19)$ & $.72(.14)$ \\
\hline
\end{tabular}


Some trends are suggested by these proportions. First, in the baseline, no-priming condition, there is an improvement with grade in the spelling of the target vowels. The achieved vowel spelling percentage does not reach ceiling at grade 4: $61 \%$ correct in the no-priming condition. This level of performance leaves room for improvement under priming conditions. Second, the proportion of correct vowel across priming conditions increases in grades 3 and 4; there does not appear to be an improvement in the earlier grades with priming.

In order to assess the effects of priming on the correct spelling of the vowels, a between-participants analysis of variance was performed with two main effects: Level of Morphological Priming (3: no-priming; only-oral priming; oral-plus-written priming); and Grade (4: 1st to 4th grade). The dependent variable was the proportion of correctly spelled vowels. The main effect of Priming was not significant $\left(\mathrm{F}_{(2,384)}=2.46, p=0.160\right)$, as expected; the main effect of Grade was significant $\left(\mathrm{F}_{(3,384)}=17.82, p<0.005\right)$ and the interaction between Priming and Grade was also significant $\left(\mathrm{F}_{(6,384)}=\right.$ $2.14, p<0.05)$. Thus the predicted interaction between priming and grade was observed.

Post-hoc tests using the Bonferroni adjustment showed that accuracy in the spelling of vowels was significantly lower in the no-priming and only-oral priming conditions than in the oral-plus-written priming condition $(p<.001)$; the only-oral priming condition did not differ significantly from the no-priming condition $(p=0.10)$. Pair-wise comparisons (using the criterion of $p<0.05$ ) showed that significant differences were observed between the oral-plus-written priming and the no-priming condition for children in grades $3(p<0.005)$ and $4(p=0.005)$. Comparisons between grade levels showed that the performance of children in grades 3 and 4 was significantly better than that of the children in grades $1(p<.001)$ and $2(p<.001)$; children in grade 4 also performed significantly better than children in grade $3(p<.001)$; the performance of children in grades 1 and 2 did not differ $(p=0.54)$.

In conclusion, the spelling of schwa vowels in derived words without priming with a morphologically related stem improves through grades but is not at ceiling in grade 4. The improvement in correct spelling of the schwa vowel in words under priming condition supports the hypothesis that priming is effective for children in the middle grades of primary school but not for the young ones. Only-oral primes did prove weaker than oral-plus-written primes, confirming their greater fragility. 


\section{Conclusions and discussion}

We conclude that there was support for the prediction that morphological priming is effective in improving the spelling of schwa vowels in the stem of derived forms for children in primary school middle grades but not for younger children. The results are consistent with the hypothesis that young children do not have a morphologically analysed representation of words in their mental lexicon. Therefore they cannot use a morphologically related prime to facilitate the spelling of schwa vowels in words, even if the prime has a clearly pronounced vowel and is presented in writing.

These results are to some extent surprising. In the oral-plus-written priming condition, why should young spellers fail to use the information that is in front of them to spell words that they may not be able to spell? The answer must be that they cannot see the relevance of the information: all the stems used in this study had a change in pronunciation from the base form to the derived form so they could not see the connection between the two forms. Thus when producing the spelling of the derived forms, they searched for phonological or whole-word representations, but not for morphologically related representations.

Their level of success on these vowels was slightly less than $50 \%$ correct. If we consider that the sounds that they were spelling, $/ \mathrm{w} /$ and $/ \mathrm{j} /$, have two possible representations in Portuguese, "o" or " $u$ " and "e" or "i", respectively, this level of accuracy suggests that their performance is at chance level. If their spelling strategies were based on letter-sound correspondences, they would be systematically choosing the incorrect vowel. This performance at chance level suggests that the children were aware that these vowel sounds are sometimes represented with " $u$ " or "i" and sometimes represented with "o" or "e", but they did not have a strategy for choosing the right vowel. A correct vowel choice would only be possible if they were using morphological spelling strategies. Because the words used in the study were low frequency words, their possibility of using whole word representation was low.

Priming was effective despite the fact that primes were presented in a sentence context, thus separated by a set of intervening items from their targets and in the absence of any explicit suggestion to the children that they could use a clue from the sentences they heard in order to help them with their spelling. Further research could investigate whether the improvement in the spelling of schwa vowels would be more marked if explicit instructions to look for a clue were used. To conclude, this study provides new evidence that morphological priming can be used successfully to enhance the spelling of schwa vowels, 
which causes difficulties for Portuguese children up to the middle grades in primary school.

The study has significant implications for educational practice, which should be put to test through further research. Morphological priming could be a tool to help children consider unexplored spelling strategies and build a new framework for thinking about spelling, which can be productively used for further learning. In Portugal, as in Brazil, primary school teachers do not seem aware of the possible value of morphological spelling strategies. Further research could focus both on teachers and students, in order to raise their awareness on how morphology can assist spelling in Portuguese.

\section{REFERENCES}

AIDINIS, A. Phonemes, morphemes and literacy development: evidence from Greek. Unpublished Ph.D. Thesis. Department of Child Development and Learning, University of London, Institute of Education, 1998.

BOWERS, J. S. The modality-specific and -nonspecific components of long-term priming are frequency sensitive. Memory \& Cognition, v. 28, n. 3, p. 406-414, 2000 .

BRYANT, P.; NUNES, T.; AIDINIS, A. Different morphemes, same spelling problems: cross-linguistic developmental studies. In: HARRIS, M.; HATANO, G. (Eds.). Learning to read and write: a cross-linguistic perspective. Cambridge: Cambridge University Press, 1999. p. 112-133.

BRYANT, P.; NUNES, T.; SNAITH, R. Children learn an untaught rule of spelling. Nature, n. 403, p. 157-158, 2000.

CARAMAZZA, A.; LAUDANNA, A.; ROMANI, C. Lexical access and inflectional morphology. Cognition, n. 28, p. 297-332, 1988.

CARSLISLE, J. F. Knowledge of derivational morphology and spelling ability in fourth, sixth, and eighth graders. Applied Psycholinguistics, n. 9, p. 247-266, 1988.

CHIALANT, D.; CARAMAZZA, A. Where is morphology and how is it processed? In: FELDMAN, L. B. (Ed.). Morphological aspects of language processing. Hillsdale (NJ): Lawrence Erlbaum, 1995. p. 55-78. 
EMMOREY, K. D. Auditory morphological priming in the lexicon. Language and Cognitive Processes, v. 4, n. 2, p. 73-92, 1989.

FARACO, C. A. Escrita e alfabetização. Características do sistema gráfico do português. São Paulo: Editora Contexto, 1992.

FORSTER, K.; AZUMA, T. Masked priming for prefixed words with bound stems: Does submit prime permit? Language and Cognitive Processes, v. 15, n. 4/5, p. 539-561, 2000.

GIRAUDO, H.; GRAIGNER, J. Effects of prime word frequency and cumulative root frequency in masked morphological priming. Language and Cognitive Processes, v. 15, n. 4/5, p. 421-444, 2000.

KARMILOFF-SMITH, A. Beyond modularity: a developmental perspective on cognitive science. Cambridge, MA: MIT Press, 1992.

KEMPLEY, S. T.; MORTON, J. The effects of priming with regularly and irregularly related words in auditory word recognition. British Journal of Psychology, n. 73 , p. 441-454, 1982.

LAUDANNA, A.; BADECKER, W.; CARAMAZZA, A. Priming homographic stems. Journal of Memory and Language, n. 28, p. 531-546, 1989.

. Processing inflectional and derivational morphology. Journal of Memory and Language, n. 31, p. 333-348, 1992.

LAUDANNA, A.; CERMELE, A.; CARAMAZZA, A. Morpho-lexical representations in naming. Language and Cognitive Processes, n. 12, p. 49-66, 1997.

LEONG, C. K. Rapid processing of base and derived forms of words and grades 4, 5 and 6 children's spelling. Reading and Writing: An Interdisciplinary Journal, n. 12, p. 277-302, 2000.

NUNES, T.; BRYANT, P. Children's reading and spelling. Beyond the first steps. London: Wiley/Blackwell, 2009.

2006.

. Improving Literacy through Teaching Morphemes. London: Routledge,

NUNES, T.; BRYANT, P.; BINDMAN, M. Learning to spell regular and irregular verbs. Reading and Writing: An Interdisciplinary Journal, n. 9, 427-449, 1997b. 
. Morphological spelling strategies: developmental stages and processes. Developmental Psychology, n. 33, p. 637-649, 1997a.

. The effects of learning to spell on children's awareness of morphology. Reading and Writing: An Interdisciplinary Journal, n. 19, p. 767-787, 2006.

NUNES, T.; BRYANT, P.; OLSSON, J. Learning morphological and phonological spelling rules: an intervention study. Reading and Writing: An Interdisciplinary Journal, n. 7, p. 289-307, 2003.

RAVEH, M.; RUECKL, J. G. Equivalent effects of inflected and derived primes: long-term morphological priming in fragment completion and lexical decision. Journal of Memory and Language, n. 42, p. 103-119, 2000.

TAFT, M.; ZHU, X. The representation of bound morphemes in the lexicon: A Chinese study. In: FELDMAN, L. B. (Ed.). Morphological aspects of language processing. Hillsdale, NJ: Lawrence Erlbaum, 1995. p. 293-316.

Texto recebido em 29 de junho de 2010.

Texto aprovado em 3 de agosto de 2010. 